\title{
Oxidation of Solid Phase and Ionic Strength Effect to the Cesium Adsorption on Pumice Tuff
}

\author{
Mohammad Rajibi, ${ }^{1 *}$, Taishi Kobayashi ${ }^{3}$, Chiaki T. Oguchi', Takayuki Sasaki ${ }^{3}$ \\ ${ }^{1}$ Graduate School of Science and Engineering, Saitama University, Saitama, Japan \\ ${ }^{2}$ Bangladesh Atomic Energy Commission, Dhaka, Bangladesh \\ ${ }^{3}$ Department of Nuclear Engineering, Kyoto University, Kyoto, Japan \\ ${ }^{4}$ Department of Civil and Environmental Engineering, Saitama University, Saitama, Japan \\ Email: "s13de056@mail.saitama-u.ac.jp, "rajib.mohammad@gmail.com
}

Received 26 January 2016; accepted 19 February 2016; published 22 February 2016

Copyright (C) 2016 by authors and Scientific Research Publishing Inc.

This work is licensed under the Creative Commons Attribution International License (CC BY). http://creativecommons.org/licenses/by/4.0/

(c) (i) Open Access

\begin{abstract}
In-situ oxidation of solid phase was considered to investigate adsorption behavior under different geochemical parameters like $\mathbf{p H}$, initial concentration and ionic strength. Pumice tuff, a potential host rock for low and intermediate radioactive wastes, has been affected by the redox zone. The characterization of the fresh and oxidized tuff was performed by X-ray diffractometer, scanning electron microscope and mercury intrusion porosimetry. In order to compare the difference of distribution coefficient $\left(K_{d}\right)$ in fresh and oxidized pumice tuffs, a batch adsorption study was carried out at the range of $\mathrm{pH}(4-12)$, ionic strength $\left(0.003,0.1,1.0\right.$ and $\left.3.0 \mathrm{~mol} / \mathrm{dm}^{3}\right)$ and initial cesium concentration $\left(10^{-4}, 10^{-5}, 10^{-6}\right.$ and $\left.10^{-7} \mathrm{~mol} / \mathrm{dm}^{3}\right)$. Based on experimental $K_{\mathrm{d}}$ values, ionic strength was found to be the most influential factor, whereas the effects of $\mathrm{pH}$, initial Cs concentration and weathering condition of pumice tuff were negligible. The recalculated $K_{d}$ values suggest that the existing surface complexation model is applicable to explain the sorption coefficients through the wide range of solution conditions.
\end{abstract}

\section{Keywords}

Oxidation, Ionic Strength, Adsorption, Cesium, Batch Experiment, Distribution Coefficient, Pumice Tuff

\section{Introduction}

Reduction phenomena of bed rock in the vicinity of waste repository by contacting the surface/subsurface water

${ }^{*}$ Corresponding author.

How to cite this paper: Rajib, M., Kobayashi, T., Oguchi, C.T. and Sasaki, T. (2016) Oxidation of Solid Phase and lonic Strength Effect to the Cesium Adsorption on Pumice Tuff. Journal of Geoscience and Environment Protection, 4, 64-73. http://dx.doi.org/10.4236/gep.2016.42008 
can lead to the formation of redox front. This can be natural, through long-term migration of groundwater through faults and fractures [1], through some geomorphological processes like weathering, denudation and diagenesis [2]-[4], or through microbial activity [5]. There can be anthropogenic processes too, through access of air into man-made excavations when oxidation occurs to previously reduced minerals by oxidizing air and/or water that diffuse(s) from the galleries into the matrix of the surrounding rock [6]. This zone may have significant effect on the adsorption of certain nuclides [7], long-term chemical stability [8], and control the mobilization and fixation of many trace elements, including potential pollutants that can be released from the wastes [9]. For any proper safety assessment for a deep geological repository, such long-term redox processes in the geosphere surrounding the repository need to be taken into account adequately [6].

Numerous fractures in host rock formation form the potential migration paths for radionuclides along the flowing groundwater. As fractures are mostly formed at the exposed or weathered part of the rock first, it becomes contaminated before the un-weathered or fresh part. Since a slight weathering of a fresh mineral surface can be expected to lead to the formation of exchange sites and increased sorption [10], the effects of such weathering (in the form of oxidation-reduction) of rock mass on the adsorption of nuclides need to be investigated. The uptake of a nuclide on a solid as a function of the nuclide concentration in the aqueous phase can be described by that adsorption reaction. It is normally represented in the form of a distribution coefficient, $K_{\mathrm{d}}$, which is important to evaluate the quality of rock formations as nuclear waste repositories.

It has been shown that the distribution coefficient values not only vary greatly between nuclides, but also as a result of aqueous and solid phase chemistry [11]-[13]. The solid phase can be easily affected by subsurface redox phenomena. However, despite having such importance of redox zone, only few studies have considered such phenomena in adsorption experiment. In most cases, the redox environment was considered only in the experimental solution in the laboratory [14]-[17]. The in-situ redox affected solid has rarely been used for any sorption study, hence the exact water-rock interaction in such solid phase is not clearly understood even though the role of the bed rock as a radionuclide retaining barrier in long geologic time is particularly important [18].

Cesium (Cs) is a common non-redox-sensitive element and important nuclide because of its frequent availability and strong effect on environment. It is also a vital constituent of low and intermediate level radioactive wastes. For this, many studies can be found in different sorption database regarding cesium adsorption reactions between ground water with host rocks surrounding a disposal site [19]-[21]. In a recent study with cesium and iodide ions on pumice tuff, it was observed that oxidation of the host rock can dissolve some minerals and may increase some elements in the groundwater which can affect the geochemical properties of nuclides significantly [22]. Nevertheless, such oxidation effect of solid phase to the adsorption has not been investigated although it can affect the surrounding rock formation by persistence of Fe-oxyhydroxides [6], changes in elemental composition [23], internal and external surface area [24] etc. Oxidation can also significantly affect some mechanical properties of rock body, like porosity, surface area, relative strength etc., mostly by dissolving different elements and forming new complexes [25] [26]. In consequence, this paper attempts to deal with the oxidation effect of the solid phase on adsorption, specifically with Cs as redox-inactive element in a wide range of geochemical environment. The results will help in describing the migration behavior of radiocesium in the subsurface environment. The related bibliographic studies also refer to our previous works [22] [27].

\section{Experimental Methods}

To investigate the Cs adsorption mechanism on fresh and oxidized solid phase, pumice tuff samples from the Takahoko Formation of Neogene Period [28] was used. It was collected from the underground research site of Japan Nuclear Fuel Limited (JNFL) located in the village of Rokkasho, Simokita Peninsula, Aomori, Japan. A so-called redox front has been identified at the site below $50 \mathrm{~m}$ from the surface where the oxidized tuff can be separated from fresh or un-oxidized tuff [29]. After studying the solid phase's physical and mechanical properties, both types of pumice tuffs have undergone adsorption experiments to determine the $K_{\mathrm{d}}$.

\subsection{Solid Phase Characterization}

Fresh and oxidized parts of rhyolitic pumice tuff, as a generic host rock for low and intermediate level waste, were differentiated on the basis of their physical, chemical and mechanical properties. Mineralogical analysis was performed by powder X-ray diffractometer using RIGAKU Rint Ultima-III system at operating conditions 
of continuous scanning between $3^{\circ}-75^{\circ}$ at $4^{\circ} / \mathrm{min}$, X-ray target of $\mathrm{CuK} \alpha$, tube voltage of $40 \mathrm{kV}$, tube current of $40 \mathrm{~mA}$, and slit arrangement of $2 / 3^{\circ}-0.3 \mathrm{~mm}-2 / 3^{\circ}-10 \mathrm{~mm}$. Scanning Electron Microscope (SEM) analysis was conducted on small fresh and oxidized pumice tuff fragments using JEOL JSM-5600LV at $20 \mathrm{kV}$ to take Secondary Electron Image (SEI). As for mechanical properties, porosity and Pore Size Distribution (PSD) were analyzed by Mercury Intrusion Porosimetry (MIP) system of Micromeritics Shimadzu AutoPore IV through low and high pressure analysis. Four samples each from fresh and oxidized pumice tuffs were used to obtain pore properties.

\subsection{Adsorption Experiments}

Distribution coefficient, $K_{\mathrm{d}}$, of a certain nuclide is the amount of that nuclide remaining in the solution after the interaction with rock or mineral surface. It is usually expressed in the logarithmic values of $\mathrm{m}^{3} / \mathrm{kg}$ yielding from batch sorption experiments carried out with the crushed materials using homogenous grain sizes due to the reported significant effect of particle size and surface area of rock body [30]. As such, powder of $150-300 \mu \mathrm{m}$ size pumice tuffs was used for batch preparation in the present research. The detail experimental method has been described in our previous studies [22] [27]. This study presents wider variation of geochemical parameters like initial Cs concentration of $10^{-4}, 10^{-5}, 10^{-6}, 10^{-7} \mathrm{~mol} / \mathrm{dm}^{3}(\mathrm{M})$, pH of 4 to 12 and ionic strength of $0,0.1,1.0$ and 3.0 $\mathrm{M} \mathrm{NaClO}_{4}$. For aging, all the samples were kept in argon filled desiccator to avoid carbonate contamination. During the aging process, the $\mathrm{pH}$ shifted until 8 - 10 weeks after the start due to the chemical oxidation of pyrite. Therefore, the contact time was taken up to 14 weeks to get equilibrium condition. Due to the $\mathrm{pH}$ adjustment, minor changes of ionic strength occurred which was found to be as low as 0.003 times and so, the minimum ionic strength was considered as $0.003 \mathrm{M}$ instead of 0 . The $K_{\mathrm{d}}$ was calculated using the following equation considering the probable dissolved concentration of Cs during aging period [27];

$$
K_{\mathrm{d}}=\frac{(\text { Conc. }[\text { ini }]+\text { Conc. }[\text { diss }])-\text { Conc. }[\text { fin }]}{\text { Conc. }[\text { fin }]} \times \frac{V}{W}
$$

where, Conc.[ini], Conc.[diss] and Conc.[fin] are initial, dissolved and final concentration of the nuclide in solution, respectively; $V$ and $W$ are the volume of the solution in $\mathrm{ml}$ and weight in g, respectively. Cs concentration was determined by Inductively Coupled Plasma Mass Spectrometry (ICP-MS, Elan DRC II, PerkinElmer) considering that the detection range of ICP-MS for Cs is $\left(10^{-8}-10^{-4} \mathrm{M}\right)$. Since the ionization efficiency of MS for Cs slightly decreases with increasing ionic strength, the matrix effect was considered in the determination of the raw concentration. Moreover, having initial high ionic strength solution, it was necessary to dilute the samples before ICP-MS measurement. The experimental $K_{d}$ values were then used in simple sorption models to recalculate the $K_{\mathrm{d}}$ values to compare with literature. To determine the dissolved concentration of Cs in the solution from pumice tuff, following separate experiment was carried out.

\subsection{Dissolution Experiment}

The dissolution experiment was conducted by complete immersion technique with the same grain sizes and solid-solution ratios as those used for the adsorption experiments. The pumice tuff powder of a weight of $8 \mathrm{~g}$ was added in $80 \mathrm{ml}$ di-ionized water in a plastic container and kept in an incubator at constant temperature of $25^{\circ} \mathrm{C}$. Initially, the solid was mixed with the solution by mild hand shaking for about 3 minutes. The $\mathrm{pH}$ and electrical conductivity (EC) were measured every 24 h using a Horiba pH meter (Model D-51) and a Yokogawa EC Meter (Model SC82), respectively, until reaching equilibrium. After every measurement, samples were mixed by hand shaking. The measurement continued for one month since there were subtle changes in EC even after reaching near equilibrium (Figure 1). After equilibrium, Cs concentration was measured by ICP-MS.

\section{Results and Discussion}

\subsection{Solid Phase Characteristics}

The physical properties provide the differences in oxidation condition of the pumice tuff (Figure 2). Tuff is a type of rock consisting of consolidated volcanic ash ejected from vents during a volcanic eruption, and pumice is a common product of explosive eruptions and has a high silica content and porosity. Visual observation is noticeably different as fresh part of studied pumice tuff is light grey to grey whereas oxidized part is yellowish 


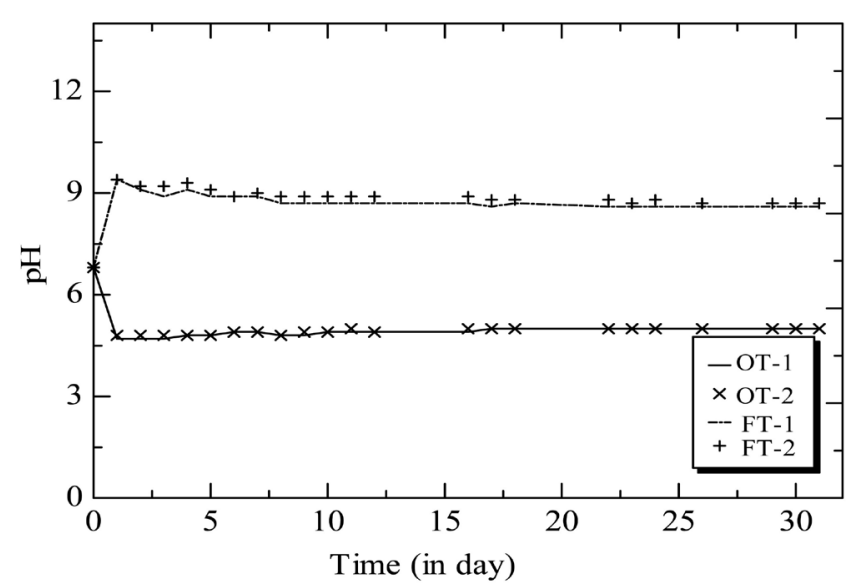

(a)

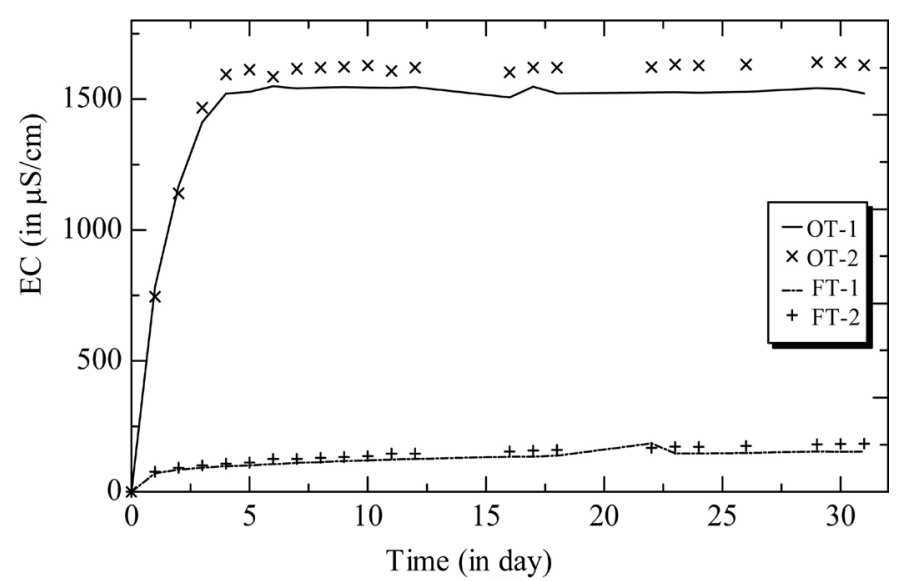

(b)

Figure 1. (a) pH and (b) EC measurement of fresh (FT) and oxidized (OT) pumice tuff in dissolution experiment. The numbers 1 and 2 after OT and FT represent the duplication of the samples.

brown probably due to being iron $\left(\mathrm{Fe}^{3+}\right.$ ) rich (Figure 2(a)). Large pumice grains and dark color minerals are distinctive in fresh part while they are not visible in oxidized one. The mineralogical composition of fresh and oxidized parts are similar with the presence of quartz $\left(\mathrm{SiO}_{2}\right)$, plagioclase $\left((\mathrm{Na}, \mathrm{Ca})(\mathrm{Si}, \mathrm{Al})_{4} \mathrm{O}_{8}\right)$ (dominantly albite), and pyrite $\left(\mathrm{FeS}_{2}\right)$. The broad halo of the X-ray spectra in the $2 \theta$ range of $15^{\circ}-35^{\circ}$ indicates amorphous glass (Figure 2(b)). According to [22], iron-titanium oxide such as ilmenite, clinopyroxene, and apatite can also be observed as the minor minerals in pumice tuff.

Regarding the pore characteristics of solid samples, both types of pumice tuffs have similar PSD beyond 10 and $0.3 \mu \mathrm{m}$ although the pore sizes of $0.3-0.03 \mu \mathrm{m}$ sizes are higher in fresh tuff (Figure 2(c)). Numbers of pores of similar diameter within $10-0.3 \mu \mathrm{m}$ size are higher in fresh tuff. Higher incremental volume in oxidized pumice tuff indicates that those similar size pores are distributed within smaller range of $7.9-10 \mu \mathrm{m}$. Fresh tuff has higher pore area (average $4.6 \mathrm{~m}^{2} / \mathrm{g}$ in fresh tuff to $2.6 \mathrm{~m}^{2} / \mathrm{g}$ in oxidized tuff) though the porosity does not vary significantly (around $49 \%$ - 50\%).

While observing through SEM, general surface area characteristics of both tuffs are similar (Figure 3(a), Figure 3(b)). However, the well-developed pore areas in fresh tuffs (Figure 3(c)) are sometimes filled up by either matrix materials or products from dissolution of weak materials in oxidized part (Figure 3(d)). These secondary materials may have destroyed smaller size pores in oxidized tuffs. Moreover, the large pumice grains are clearly seen in fresh tuffs with connected pore like features (Figure 3(e)). Such elongate shaped features give the larger surface area which can be evident in the difference in pore area. Since highly porous materials are reported to be damaged by oxidation [31] and by reduction of micro pores during weathering [32], the pores in oxidized tuff are considered to be destroyed. This higher volume of similar size pores in fresh tuff creates higher surface area responsible for water-rock interaction. Twice the total pore area in fresh tuff also indicates 
(a)

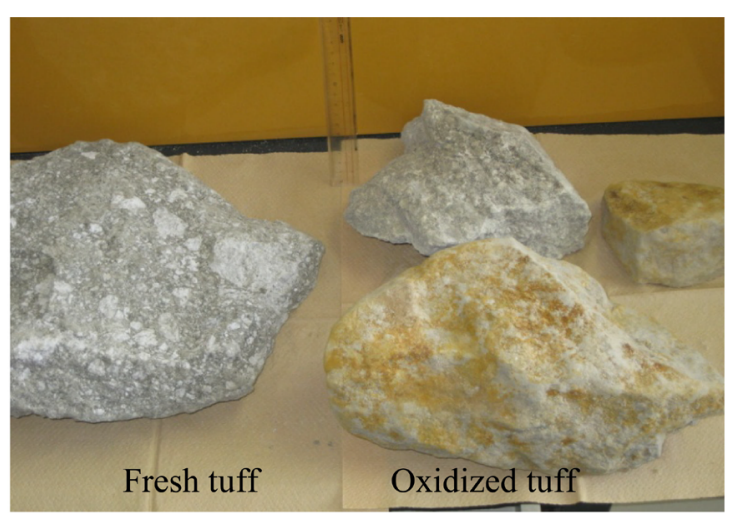

(b)

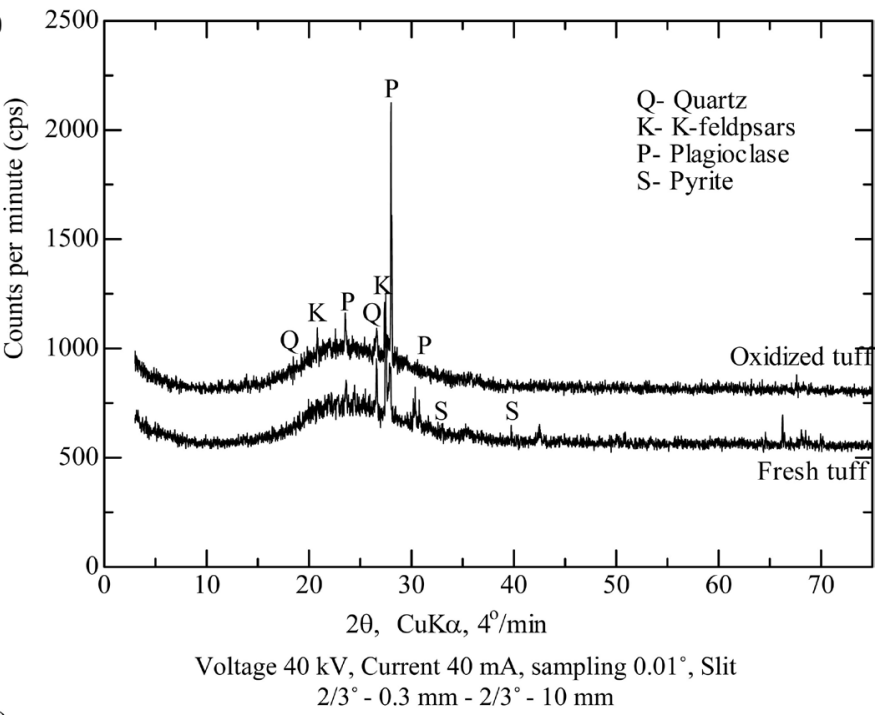

(c)

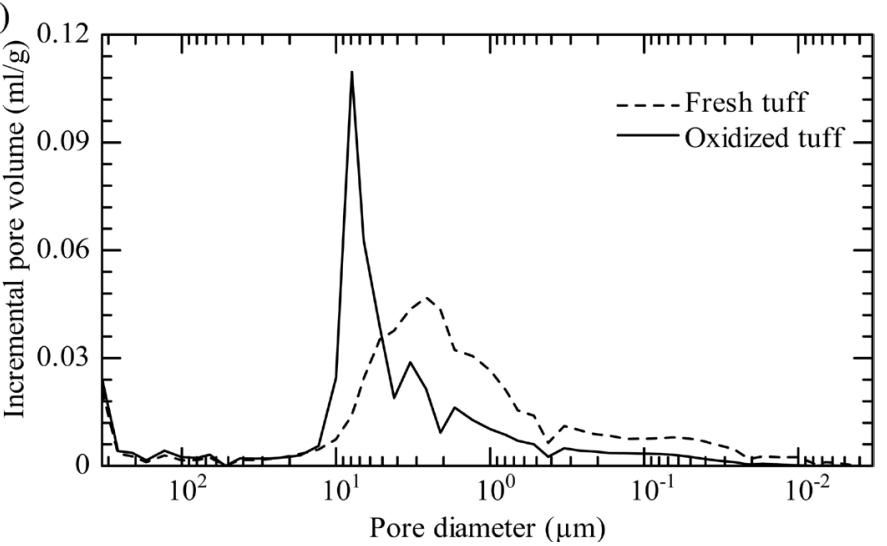

Figure 2. Solid phase characteristics of the fresh (FT) and oxidized (OT) pumice tuff. (a) Physical appearance, (b) XRD analysis and (c) PSD analysis.

the presence of higher surface area available for adsorption.

\section{2. pH Shifting during Aging Period}

Generally, $\mathrm{pH}$ values shift to neutral unless affected by external factors. In this study, fresh pumice tuff solution showed that tendency when $\mathrm{pH}$ initially (in the 2nd week) shifted towards neutral, around 7 - 8. On the contrary, $\mathrm{pH}$ shifted downward to 3.5 - 4 for oxidized pumice tuff due to the oxidation of pyrites [26]. In field condition, pyrites, an important sulphur mineral constituent in pumice tuff, can be oxidized in suitable geochemical envi- 
ronment according to following overall reactions [34]-[36];

$$
\begin{aligned}
& \mathrm{FeS}_{2}+3.5 \mathrm{O}_{2}+\mathrm{H}_{2} \mathrm{O} \rightarrow \mathrm{Fe}^{2+}+2 \mathrm{SO}_{4}^{2-}+2 \mathrm{H}^{+} \\
& \mathrm{Fe}^{2+}+0.25 \mathrm{O}_{2}+\mathrm{H}^{+} \rightarrow \mathrm{Fe}^{3+}+0.5 \mathrm{H}_{2} \mathrm{O} \\
& \mathrm{FeS}_{2}+14 \mathrm{Fe}^{3+}+8 \mathrm{H}_{2} \mathrm{O} \rightarrow 15 \mathrm{Fe}^{2+}+2 \mathrm{SO}_{4}^{2-}+16 \mathrm{H}^{+}
\end{aligned}
$$

After the 2nd week, the $\mathrm{pH}$ shifting decreased because of adjustment in the previous week and then every other week, the decrease of $\mathrm{pH}$ reduced more due to re-adjustments. We observed that $\mathrm{pH}$ shifting was not significant after 12 weeks except for several samples (with $\mathrm{pH} 6$ and 8) and hence considered it had reached equili-
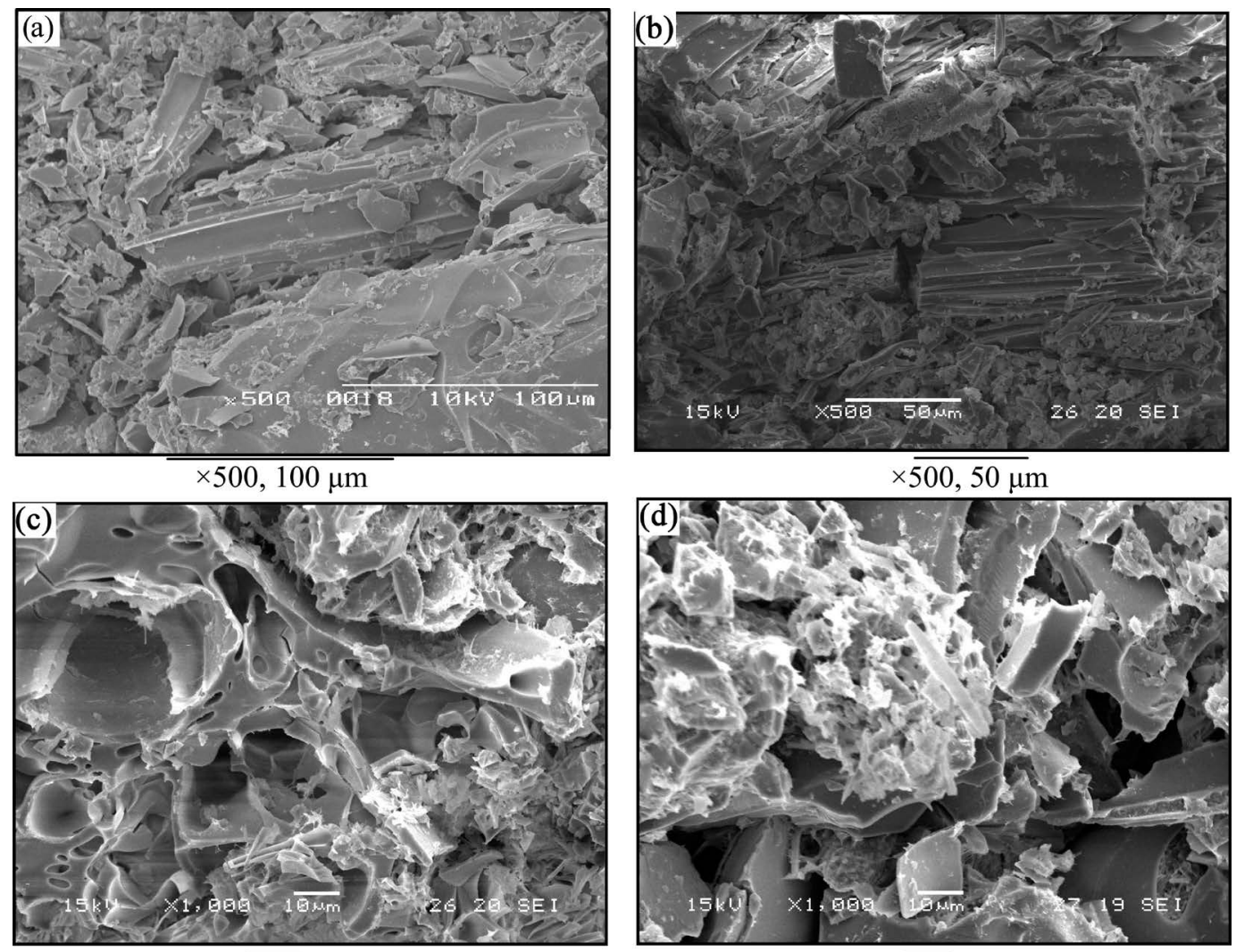

$$
\times 1000,10 \mu \mathrm{m} \quad \times 1000,10 \mu \mathrm{m}
$$

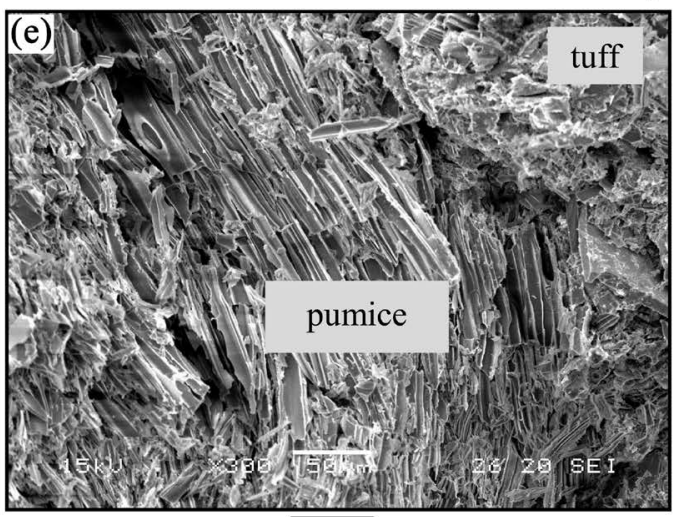

$\times 10 \overline{0,50} \mu \mathrm{m}$

Figure 3. Secondary Electron Image (SEI) of fresh tuff ((a), (c)) and oxidized tuff ((b), (d)) indicating different pore characteristics; (e) shows the difference of pores between tuff and pumice in fresh part which are not visible in oxidized part. 
brium condition. Samples with initial pH of 6 and 8 were still found to be shifting even in the 14th week because of being at near neutral $\mathrm{pH}$ region where only small amount of $\mathrm{pH}$ adjusting solution has a large effect.

\subsection{Cesium Adsorption on Pumice Tuff}

Three parameters- $\mathrm{pH}$, ionic strength, and the initial nuclide concentrations were expected to be responsible for the variation in the $K_{\mathrm{d}}$ values. The dissolved concentration of Cs at equilibrium $\mathrm{pH}$ and EC was found to be insignificant comparing to the initial concentration. For both types of pumice tuffs, they were determined in the order of $5.5-5.9 \times 10^{-9} \mathrm{M}$. This concentration is essentially near to the background value of analyzing solution. Hence, this negligible dissolved concentration of Cs in Equation (1) was considered as 0.

Ionic strength or salt concentration of the solutions was found to be the most influential parameter whereas the $\mathrm{pH}$ and the initial Cs concentration were found to have little effect on the $K_{\mathrm{d}}$ values (Figure 4). Experimental results showed that with the increase of ionic strength, $K_{\mathrm{d}}$ of Cs apparently decreases, indicating the competition of the electrolyte $\mathrm{Na}^{+}$with the sorption of $\mathrm{Cs}^{+}$. Such ionic strength dependency was observed for both fresh and oxidized pumice tuff. For low ionic strength (less than or equal to $1.0 \mathrm{M}$ ), both fresh and oxidized pumice tuff yielded similar order of $K_{\mathrm{d}}$ for all initial Cs concentrations which is slightly higher than higher ionic strength $(3.0 \mathrm{M})$ solution in Cs concentration of $10^{-4} \mathrm{M}$. This variation becomes more significant at lower $\mathrm{Cs}^{+}$concentrations like $10^{-5} \mathrm{M}$. For $10^{-6}$ and $10^{-7} \mathrm{M} \mathrm{Cs}^{+}$concentration at higher ionic strength $(3.0 \mathrm{M}), K_{\mathrm{d}}$ values could not be determined, probably due to out of detection limit of Cs measurement. When initial Cs concentration becomes as low as $10^{-6}$ to $10^{-7} \mathrm{M}$, more clear influence of ionic strength was observed. For example, the $K_{\mathrm{d}}$ values were inversely proportional to ionic strength at initial Cs concentration of $10^{-6}$ to $10^{-7} \mathrm{M}$. Independency on initial
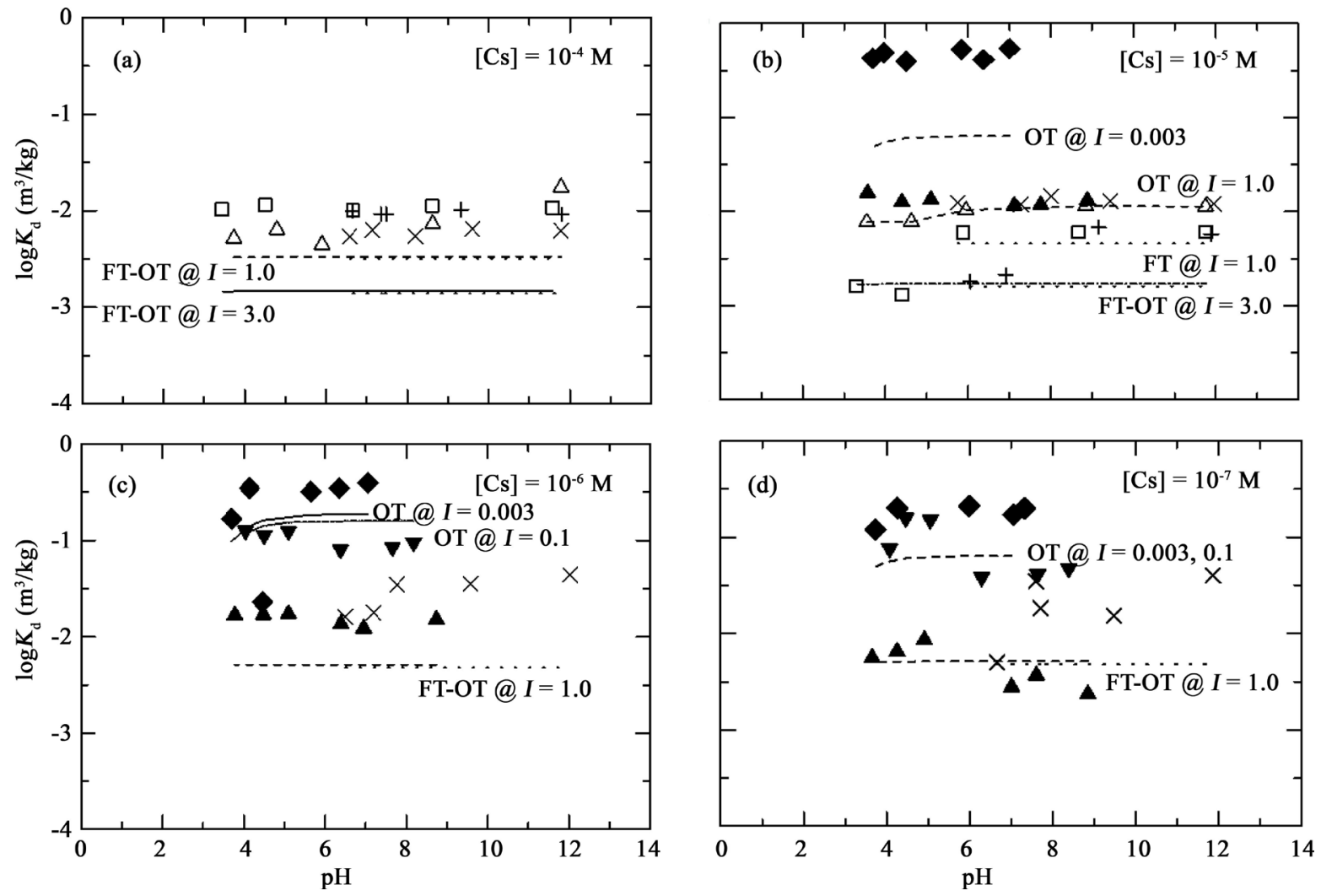

Figure 4. Influence of $\mathrm{pH}$ on distribution coefficients of Cs on both fresh (FT) and oxidized (OT) pumice tuff at different ionic strength (I) and initial Cs concentrations ((a)-(d)). Symbols $\nabla / \vee, \nabla / \nabla, \triangle / \mathbf{\Delta}$ and $\square$ are the measured values for $I=$ $0.003,0.1,1.0$, and 3.0, respectively for oxidized tuff; $\times$ and + are for $I=1.0$ and 3.0, respectively for fresh tuff where empty symbols are for this study and filled symbols are from [22]. Curves represent the recalculated $K_{\mathrm{d}}$ values of the experimental data by the surface complexation model at corresponding ionic strength mentioned with types of pumice tuff (FT and OT). Note that the curves for recalculated lines for $I=0.003,0.1$ and few 1.0 were for tuff only, separated from similar solid phase of pumice tuff. 
concentration suggests that saturation of the surface sites didn't occur until the investigated highest Cs concentration $\left(10^{-4} \mathrm{M}\right)$.

Overall, fresh and oxidized pumice tuff did not show any major difference in $K_{\mathrm{d}}$ until initial Cs concentrations of $10^{-6}$ and $10^{-7} \mathrm{M}$ where slightly decreased values were observed in oxidized part. This difference is better observed at ionic strength less than $1.0 \mathrm{M}$ which is probably due to the difference in pore size distribution in oxidized pumice tuff. The MIP study showed that smaller pores have reduced considerably in oxidized part which may have reduced the sorption surface sites. Though weathering of mineral surface may create new surface area for adsorption [10], lack of appropriate mineral surface in pumice tuff might be the reason for not having enough surface area. Weathering generated materials (e.g. clay particles) were also found at negligible quantity. Moreover, oxidation phenomena have destroyed the regular surfaces of fresh tuff as observed in SEM.

Furthermore, ionic strength dependency is reduced in Cs concentration more than $10^{-5} \mathrm{M}$. Especially at $10^{-4}$ $\mathrm{M}$, similar $K_{\mathrm{d}}$ values in different ionic strength is assumed to be due to saturation of surface sites by $\mathrm{Cs}^{+}$. This also can be observed with increasing $\mathrm{Na}^{+}$in Cs concentrations $10^{-6}$ and $10^{-7} \mathrm{M}$. All these characteristics are found similar for both fresh and oxidized pumice tuff and in good agreement with Cs adsorption on fresh tuff in previous study [22]. Several very high values above neutral $\mathrm{pH}$ at low Cs concentration may indicate small $\mathrm{pH}$ dependency if low pH $K_{\mathrm{d}}$ values are considered (Figure 4(c), Figure 4(d)). Although, as fresh pumice tuff solution didn't have any $\mathrm{pH}$ less than neutral, such dependency cannot be confirmed.

Pumice tuff is generally composed of some microcrystalline mineral components of mostly plagioclase feldspar, quartz and others. The mixture of fine mineral particles in this volcanic glass is very difficult to isolate from each other. As such, simple one site surface complexation model for predicting $K_{\mathrm{d}}$ values for tuff has been successfully applied in some previous researches [22] [33]. Considering pumice tuff as the same solid phase, the analogous mechanism from [22] was assumed for the present case and the $K_{\mathrm{d}}$ values were recalculated (Figure 4). The results show good agreement for few samples, whereas not good for few. One reason for poor matching could be due to the number of surface site difference (as evident in the large difference of the surface area between fresh and oxidized tuff). The determination of precise surface sites is needed for further study. The recalculated $K_{\mathrm{d}}$ values also indicate that $\mathrm{pH}$ dependency may appear for higher $K_{\mathrm{d}}$ values at low ionic strength. It also confirms that the surface complexation model is applicable for high ionic strength too.

\section{Conclusion}

From the conventional batch experiments with both fresh and oxidized pumice tuff, it can be concluded that Cs adsorption on pumice tuff is mainly ionic strength dependent and not depending of $\mathrm{pH}$ and initial concentration. No significant differences have been observed due to oxidation of pumice tuff at high initial concentration and high ionic strength; however, at low Cs concentrations of $10^{-6}$ and $10^{-7} \mathrm{~mol} / \mathrm{dm}^{3}$, and low ionic strength (less than $1.0 \mathrm{~mol} / \mathrm{dm}^{3}$ ), marginally decreased sorption can be observed in oxidized tuff. This is due to the smaller amount of pore area in oxidized tuff resulted from the less number of smaller pores and destruction of available surface area by oxidation. Despite having significant difference in physical and mechanical properties between fresh and oxidized tuffs, such marginal variation of sorption coefficients is not clear though. To get a clear explanation, detail analysis of the sorption site properties should be investigated. Pore properties and pore size distribution of both types of tuffs might be a helpful tool for that.

\section{Acknowledgements}

Authors are grateful to Japan Nuclear Fuel Limited (JNFL) for providing the pumice tuff samples. The research work was partially funded by Joint Japan-World Bank Graduate Scholarship Program.

\section{References}

[1] Shiroya, K. (2014) An Application of Terrestrial Cosmogenic Nuclides to Stability Assessment of Long-Term Geological Environment. Transactions, Japanese Geomorphological Union, 35, 187-197.

[2] Carignan, R. and Nriagu, J.O. (1985) Trace Metal Deposition and Mobility in Sediments of Two Lakes near Sudbury, Ontario. Geochimica et Cosmochimica Acta, 49, 1753-1764. http://dx.doi.org/10.1016/0016-7037(85)90146-2

[3] Thomson, J., Higgs, N.C., Croudace, I.W., Colley, S. and Hydes, D.J. (1993) Redox Zonation of Elements at an Oxic/ Post-Oxic Boundary in Deep-Sea Sediments. Geochimica et Cosmochimica Acta, 57, 579-595. http://dx.doi.org/10.1016/0016-7037(93)90369-8 
[4] Williamson, M.A. and Parnell Jr., R.A. (1994) Partitioning of Copper and Zinc in the Sediments of a High-Elevation Alkaline Lake, East-Central Arizona, USA. Applied Geochemisty, 9, 597-608. http://dx.doi.org/10.1016/0016-7037(93)90369-8

[5] Gerlach, R., Cunningham, A.B. and Caccavo Jr., F. (1998) Formation of Redox-Reactive Subsurface Barriers Using Dissimilatory Metal-Reducing Bacteria. Proceedings of the Conference on Hazardous Waste Research, Utah, 18-21 May 1998, 209-223.

[6] Yoshida, H., Metcalfe, R., Yamamoto, K., Murakami, Y., Hoshii, D., Kanekiyo, A., Naganuma, T. and Hayashi, T. (2008) Redox Front Formation in an Uplifting Sedimentary Rock Sequence: An Analogue for Redox-Controlling Processes in the Geosphere around Deep Geological Repositories for Radioactive Waste. Applied Geochemistry, 23, 2364-2381. http://dx.doi.org/10.1016/j.apgeochem.2008.03.015

[7] Ferris, F.G., Hallberg, R.O., Lyven, B. and Pedersen, K. (2000) Retention of Strontium, Cesium, Lead and Uranium by Bacterial Iron Oxides from a Subterranean Environment. Applied Geochemistry, 15, 1035-1042. http://dx.doi.org/10.1016/S0883-2927(99)00093-1

[8] Anderson, C.R., James, E.C., Fru, E.C., Kennedy, C.B. and Pedersen, K. (2006) In Situ Ecological Development of a Bacteriogenic Iron Oxide-producing Microbial Community from a Subsurface Granitic Rock Environment. Geobiology, 4, 29-42. http://dx.doi.org/10.1111/j.1472-4669.2006.00066.x

[9] Hu, Q.H., Zavarin, M. and Rose, T.P. (2008) Effect of Reducing Groundwater on the Retardation of Redox-Sensitive Radionuclides. Geochemical Transaction, 9, 12. http://dx.doi.org/10.1186/1467-4866-9-12

[10] Torstenfelt, B., Andersson, K. and Allard, B. (1982) Sorption of Strontium and Cesium on Rocks and Minerals. Chemical Geology, 36, 123-137. http://dx.doi.org/10.1016/0009-2541(82)90042-0

[11] Delegard, C.H. and Barney, G.S. (1983) Effects of Hanford High-Level Waste Components on Sorption of Cobalt, Strontium, Neptunium, Plutonium, and Americium of Hanford Sediments. IAEA INIS (RHO-RE-ST-1 P), 14, 68 p.

[12] Kaplan, D.I., Hunter, D.B., Bertsch, P.M., Bajt, S. and Adriano, D.C. (1994) Application of Synchrotron X-Ray Fluorescence Spectroscopy and Energy Dispersive X-Ray Analysis to Identify Contaminant Metals on Groundwater Colloids. Environmental Science and Technology, 28, 1186-1189. http://dx.doi.org/10.1021/es00055a033

[13] Kaplan, D.I., Seme, R.J. and Piepkho, M.G. (1995) Geochemical Factors Affecting Radionuclide Transport through Near and Far Fields at a Low-Level Waste Disposal Site. IAEA INIS (PNL-10379), 26, 82 p. http://dx.doi.org/10.2172/28418

[14] Mucciardi, A.N., Johnson, T.C. and Saunier, J. (1979) Statistical Investigation of the Mechanics Controlling Radionuclide Sorption. Annual Report, ADI Ref. 548, Battelle-Pacific Northwest Laboratories, Richland.

[15] Berci, K., Deak, J., Friedrich, V., Hazi, E., Juhasz, J., Maleczki, E. and Mozjes, A. (1989) Safety Assessment and Investigations for a Shallow Land Disposal Facility in Hungary. Proceedings of the International Symposium on Management of Low and Intermediate Level Radioactive Wastes 1988, IAEA, Vienna, Vol. 1, 163-178.

[16] Yucel, H. and Ozmen, A. (1996) Sorption and Migration of ${ }^{137}$ Cs Attached to Organic Materials of Tea in Silty Clay Soil. Radiation Physics and Chemistry, 47, 117-123. http://dx.doi.org/10.1016/0969-806X(94)00144-9

[17] Poinssot, C., Baeyens, B. and Bradbury, M.H. (1999) Experimental and Modeling Studies of Cesium Sorption of Illite. Geochemica et Cosmochimica Acta, 63, 3217-3227. http://dx.doi.org/10.1016/S0016-7037(99)00246-X

[18] Beall, G.W., Ketelle, B.H., Haire, R.G. and O’Kelley, G.D. (1979) Sorption Behavior of Trivalent Actinides and Rare Earths on Clay Minerals. In: Fried, S., Ed., Radioactive Waste in Geologic Storage, IAEA INIS, Vienna, 201-213. http://dx.doi.org/10.1021/bk-1979-0100.ch012

[19] Cantrell, K.J., Serne, R.J. and Last, G.V. (2003) Hanford Contaminant Distribution Coefficient Database and Users Guide. Pacific Northwest Laboratory, Washington DC, PNNL-13895, Rev-1. http://dx.doi.org/10.2172/15010213

[20] JAEA-SDB (2014) Japan Atomic Energy Agency Sorption Database. http://www.jaea.go.jp/04/tisou/english/database/database.html

[21] GERM (2015) Geochemical Earth Reference Model Partition Coefficient Database. http://earthref.org/KDD/

[22] Rajib, M., Sasaki, T., Kobayashi, T., Miyauchi, Y., Takagi, I. and Moriyama, H. (2011) Analysis of Sorption Behavior of Cesium and Iodide Ions on Pumice Tuff. Journal of Nuclear Science Technology, 48, 950-957. http://dx.doi.org/10.1080/18811248.2011.9711781

[23] Haering, K.C., Daniels, W.L. and Roberts, J.A. (1992) Changes in Mine Soil Properties Resulting from Overburden Weathering. Journal of Environmental Quality, 22, 194-200. http://dx.doi.org/10.2134/jeq1993.00472425002200010026x

[24] Fischer, C. and Gaupp, R. (2005) Change of Black Shale Organic Material Surface Area during Oxidative Weathering: Implications for Rock-Water Surface Evolution. Geochimica et Cosmochimica Acta, 69, 1213-1224. http://dx.doi.org/10.1016/j.gca.2004.09.021 
[25] Chigira, M. and Oyama, T. (1999) Mechanism and Effect of Chemical Weathering of Sedimentary Rocks. Engineering Geology, 55, 3-14. http://dx.doi.org/10.1016/S0013-7952(99)00102-7

[26] Oyama, T. and Chigira, M. (2000) Weathering Rate of Mudstone and Tuff on Old Unlined Tunnel Walls. Engineering Geology, 55, 15-27. http://dx.doi.org/10.1016/S0013-7952(99)00103-9

[27] Rajib, M., Oguchi, C.T., Sasaki, T. and Kobayashi, T. (2015) Strontium Dissolution Effect on the Adsorption Experiment with Rhyolitic Pumice Tuff. Geochemical Journal, 49, 539-548. http://dx.doi.org/10.2343/geochemj.2.0383

[28] Sasaki, T. (2005) The Site Investigation at the Next Rokkasho Disposal Facility—Disposal at around 50 - $100 \mathrm{~m}$ Depth. Proceedings of GLOBAL 2005, Tsukuba, 9-13 October 2005, Paper No. 069.

[29] Oyama, T., Inohara, Y. and Nagaoka, T. (2007) Development of the Investigation and Evaluation Method for Geochemical Condition of Underground-In-Situ Redox Conditions and Its Prediction at the Rokkasho Site. Civil Engineering Research Laboratory Report No. N07001. (In Japanese with English Abstract)

[30] Rogers, P.S.Z. and Meijer, A. (1993) Dependence of Radionuclide Sorption on Sample Grinding Surface Area, and Water Composition. Proceedings of International High Level Radioactive Waste Management Conference (LA-UR-93270), 2, 1509-1516.

[31] Kim, M., Yun, C.H., Kim, Y.J., Park, C.R. and Inagaki, M. (2002) Changes in Pore Properties of Phenol Formaldehyde-Based Carbon with Carbonization and Oxidation Conditions. Carbon, 40, 2003-2012. http://dx.doi.org/10.1016/S0008-6223(02)00058-1

[32] Oguchi, C.T. and Matsukura, Y. (1999) Microstructural Influence on Strength Reduction of Porous Rhyolite during Weathering. Zeitschrift fur Geomorphologie, Supplement Band, 119, 91-103.

[33] Sasaki, T., Terakado, Y., Kobayashi, T., Takagi, I. and Moriyama, H. (2007) Analysis of Sorption Behavior of Cesium Ion on Mineral Components of Granite. Journal of Nuclear Science Technology, 44, 641-648. http://dx.doi.org/10.1080/18811248.2007.9711852

[34] Rimstidt, J.D. and Vaughan, D.J. (2003) Pyrite Oxidation: A State-of-the-Art Assessment of the Reaction Mechanism. Geochimica et Cosmochimica Acta, 67, 873-880. http://dx.doi.org/10.1016/S0016-7037(02)01165-1

[35] Chandra, A.P. and Gerson, A.R. (2010) The Mechanisms of Pyrite Oxidation and Leaching: A Fundamental Perspective. Surface Science Reports, 65, 293-315. http://dx.doi.org/10.1016/j.surfrep.2010.08.003

[36] Molson, J.W., Fala, O., Aubertin, M. and Bussière, B. (2005) Numerical Simulations of Pyrite Oxidation and Acid Mine Drainage in Unsaturated Waste Rock Piles. Journal of Contaminant Hydrology, 78, 343-371.

http://dx.doi.org/10.1016/j.jconhyd.2005.06.005 